\title{
Blended phenotype of adult-onset Alexander disease and spinocerebellar ataxia type 6
}

Takashi Odo, MD, Tomoko Okamoto, MD, PhD, Noriko Sato, MD, PhD, and Yuji Takahashi, MD, PhD

Neurol Genet 2020;6:e522. doi:10.1212/NXG.0000000000000522
Correspondence

Dr. Takahashi

yutakahashi@ncnp.go.jp

Alexander disease is an autosomal dominant hereditary disease characterized by progressive spastic paraplegia, ataxia, and bulbar symptoms caused by mutations in the glial fibrillary acidic protein (GFAP) gene. Previous nation-wide surveillance revealed that the prevalence rate in Japan is estimated at 1 in 2.7 million people. ${ }^{1}$ Meanwhile, SCA6 is an autosomal dominant spinocerebellar ataxia characterized by adult-onset pure cerebellar ataxia. The prevalence of SCA6 is estimated to be 1 in 100,000 people in Japan. ${ }^{2}$ Here, we report an extremely rare case presenting with a blended phenotype of adult-onset Alexander disease and SCA6.

\section{Clinical report}

The patient was a 57-year-old woman presenting with progressive ataxia, facial and limb numbness, dysarthria, and dysphagia. Familial history showed that her father was genetically diagnosed with SCA6 (figure, A). At age 35 years, the patient experienced clumsiness in her right hand. At age 45 years, she developed rotation vertigo and visited our department. Her familial history suggested the diagnosis of SCA6, which was genetically confirmed. She gradually developed mild dysarthria since then, although she did not experience difficulty in verbal communication. At age 54 years, numbness appeared in both upper limbs and the lower face. At age 55 years, she developed dysphagia and noticed rapid exacerbation of dysarthria to the point that verbal communication became difficult. Neurologic examination showed cerebellar ataxia, dysarthria, dysphagia, spastic paraplegia, and sensory disturbance in all modalities in the extremities and lower face. MRI showed severe atrophy of the medulla oblongata and cervical spinal cord with preserved basal pons, which is called tadpole appearance. The anterior portion of the medulla oblongata showed high-intensity signals on T2-weighted MRI. The midbrain tegmentum and the cerebellum were also atrophic (figure, B-D). All these MR findings are characteristic of Alexander disease.

Her DNA sample was obtained with IRB-approved informed consent. PCR-based fragment analysis was performed to detect triplet repeat expansions in CACNA1A. Direct nucleotide sequencing analysis was conducted for whole exons of GFAP with specific genomic primers (supplemental method e-1, links.lww.com/NXG/A326). The mutational analysis revealed both an expansion of the CAG repeat (23 repeats) in CACNA1A and a known heterozygous point mutation in the GFAP gene (c.827G>T, p.R276L) (figure, f).

Her mother had developed difficulty in walking at age 66 years and was diagnosed clinically with amyotrophic lateral sclerosis. However, her brain MRIs were also suggestive of Alexander disease (figure, e), although cerebellar atrophy was less severe than in the proband. Based on the clinical radiologic findings and genetic data, we concluded that the proband inherited Alexander disease from her mother and SCA6 from her father and presented with a blended phenotype of both diseases.

From the Department of Neurology (T. Odo, T. Okamoto, Y.T.), National Center Hospital, National Center of Neurology and Psychiatry; and Department of Radiology (N.S.), National Center Hospital, National Center of Neurology and Psychiatry.

The Article Processing Charge was funded by the authors.

Go to Neurology.org/NG for full disclosures. Funding information is provided the end of the article.

This is an open access article distributed under the terms of the Creative Commons Attribution-NonCommercial-NoDerivatives License 4.0 (CC BY-NC-ND), which permits downloading and sharing the work provided it is properly cited. The work cannot be changed in any way or used commercially without permission from the journal. 

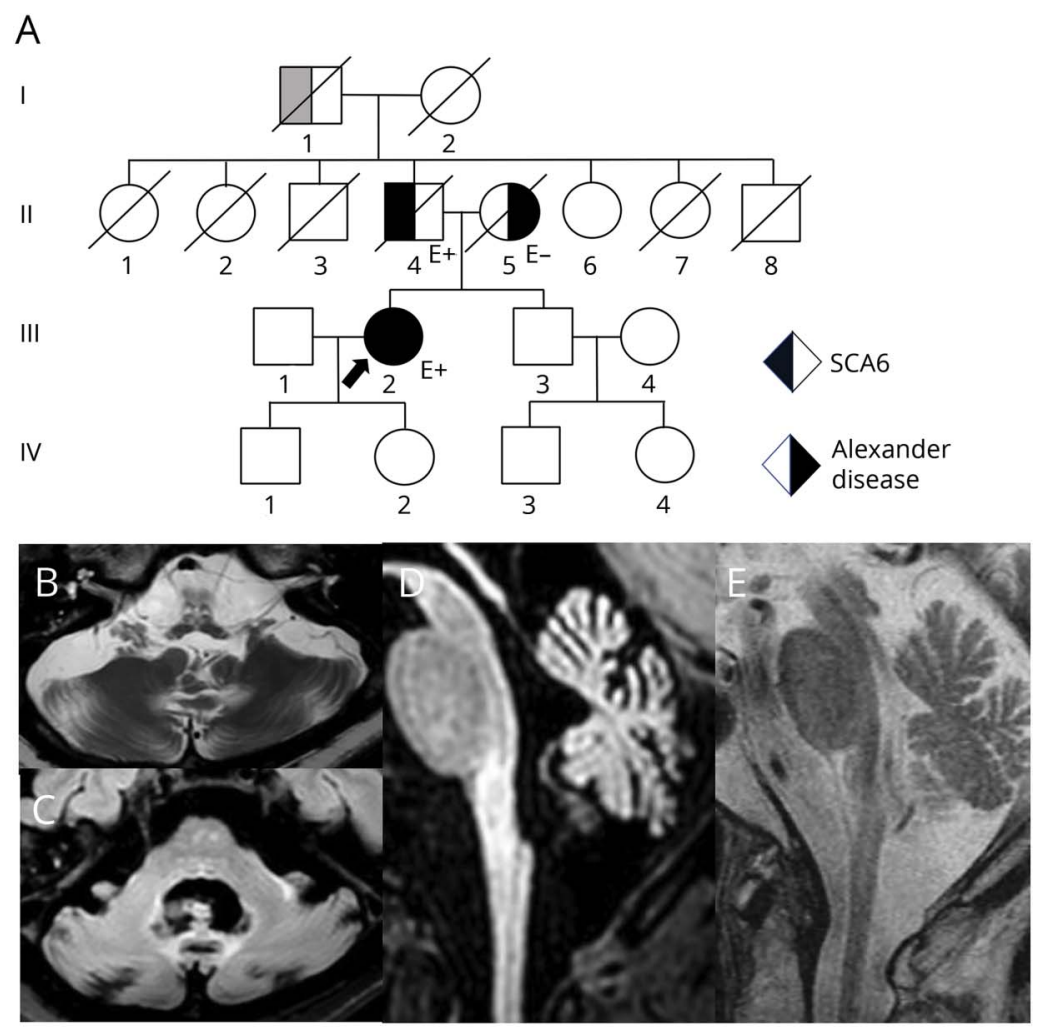

$\mathrm{F}$

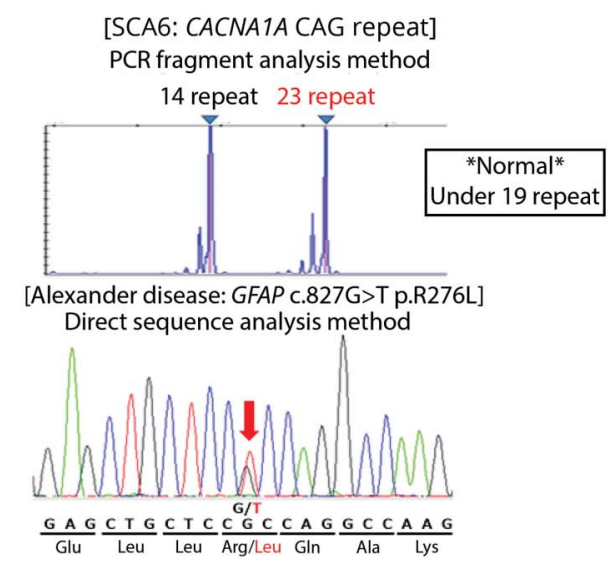

(A) Pedigree chart of the family. The proband is shown with an arrow. Those who underwent genetic tests are indicated as E+ and not as E-. Patients whose diagnosis was established as corresponding diseases are shown in black and suggestive but not established in gray. Her paternal grandfather developed a progressive gait abnormality suggestive of SCA6. Her mother was diagnosed as Alexander disease based on typical brain MRI findings, although she did not undergo genetic tests. (B-E) Brain MRIs. T2-weighted images of the proband $(B)$ and her mother $(E)$ and fluid-attenuated inversion recovery (FLAIR) images of the proband $(C, D)$ showed atrophy of the midbrain, cerebellum, medulla, and upper cervical spinal cord, the latter 2 designated as tadpole appearance characteristic for Alexander disease. High-intensity signals were observed in the dentate nucleus $(C)$ and medulla oblongata $(B, D)$ in the proband. Cerebellar atrophy was more severe in the proband than in her mother $(D, E)$, presumably due to concomitant SCA6. (F) Mutational analysis of the proband. The upper row: PCR fragment analysis for the triplet repeat expansion in the SCA6 locus. The lower row: an electropherogram of a GFAP mutation c.827G $>$ T (p.R276L). An arrow shows the heterozygous mutation in GFAP. GFAP = glial fibrillary acidic protein.

\section{Discussion}

Alexander disease is divided into 3 types based on location: type 1 is the cerebral dominant type, type 2 is the medulla oblongata/ spinal cord dominant type, and type 3 is the mixed type. According to clinical symptoms and imaging findings, our patient was classified as type 2 . Previous reports have shown that patients with the mutation also presented with type 2 phenotypes, predominantly bulbar and pyramidal signs with minimal cerebellar ataxia. In these individuals, brain MRI revealed typical T2-weighted high-intensity lesions in the medulla oblongata and cervical lesion and mild cerebellar atrophy. ${ }^{3,4}$ In contrast, our patient developed ataxia as the initial symptom, suggesting that concomitant SCA6 played a major role in the symptomatic onset with the subsequent rapid deterioration caused by the GFAP mutation. Whether the underlying degeneration process of SCA6 triggered the rapid deterioration caused by the GFAP mutation is an intriguing issue to be discussed. In the animal model of SCA1, activation of astrocytes with increased expression of GFAP occurred early in the absence of neuronal death. This suggests that expanded polyglutamine stretches per se are the trigger of astrocyte pathology. ${ }^{5}$ Likewise, astrocytic expanded polyglutamine affected glial glutamatergic clearing and caused neuronal dysfunction in Huntington disease model mice. ${ }^{6}$ Therefore, it is plausible to hypothesize that accumulation of expanded polyglutamine stretches and dysfunction of GFAP proteins might confer synergistic effects on the clinical course in our patient. Accumulation of similar patients or model animal 
experiments using double-transgenic mice would be warranted to investigate the hypothesis. Comprehensive gene analysis using next-generation sequencers has occasionally revealed pathogenic mutations of multiple mendelian inherited diseases, and the concept of blended phenotype has been proposed. ${ }^{7}$ This report describes a blended phenotype caused by an extremely rare combination of Alexander disease and SCA6. A take-home message is that in cases in which clinical course and physical examination are atypical or complicated, and multiple familial history exists, the possibility of blended phenotypes should be taken into consideration.

\section{Acknowledgment}

The authors thank Shoko Watanabe, PhD, for technical assistance including mutational analysis.

\section{Study funding}

No targeted funding reported.

\section{Disclosure}

The authors report no disclosures. Go to Neurology.org/NG for full disclosures.

\section{Publication history}

Received by Neurology: Genetics June 1, 2020. Accepted in final form August 19, 2020.

\section{Appendix Authors}

\begin{tabular}{lll}
\hline Name & Location & Contribution \\
\hline $\begin{array}{l}\text { Takashi } \\
\text { Odo, MD }\end{array}$ & $\begin{array}{ll}\text { National Center Hospital, } \\
\text { National Center of } \\
\text { Neurology and Psychiatry } \\
\text { (NCNP), Tokyo }\end{array}$ & $\begin{array}{l}\text { Clinical analysis; study } \\
\text { concept or design; } \\
\text { acquisition of data; analysis } \\
\text { and interpretation of data; } \\
\text { and drafting/revising the } \\
\text { manuscript for content }\end{array}$ \\
& & \\
\hline
\end{tabular}

Appendix (continued)

\begin{tabular}{|c|c|c|}
\hline Name & Location & Contribution \\
\hline $\begin{array}{l}\text { Tomoko } \\
\text { Okamoto, } \\
\text { MD, PhD }\end{array}$ & $\begin{array}{l}\text { National Center Hospital, } \\
\text { NCNP, Tokyo }\end{array}$ & $\begin{array}{l}\text { Clinical analysis; study } \\
\text { concept or design; } \\
\text { acquisition of data; analysis } \\
\text { and interpretation of data; } \\
\text { and revising the manuscript } \\
\text { for content }\end{array}$ \\
\hline $\begin{array}{l}\text { Noriko } \\
\text { Sato, MD, } \\
\text { PhD }\end{array}$ & $\begin{array}{l}\text { National Center Hospital, } \\
\text { NCNP, Tokyo }\end{array}$ & $\begin{array}{l}\text { Clinical analysis; acquisition } \\
\text { of data; analysis and } \\
\text { interpretation of data; and } \\
\text { revising the manuscript for } \\
\text { content }\end{array}$ \\
\hline $\begin{array}{l}\text { Yuji } \\
\text { Takahashi, } \\
\text { MD, PhD }\end{array}$ & $\begin{array}{l}\text { National Center Hospital, } \\
\text { NCNP, Tokyo }\end{array}$ & $\begin{array}{l}\text { Study supervision; study } \\
\text { concept or design; } \\
\text { acquisition of data; analysis } \\
\text { and interpretation of data; } \\
\text { drafting/revising the } \\
\text { manuscript for content; } \\
\text { and study } \\
\text { supervision }\end{array}$ \\
\hline
\end{tabular}

\section{References}

1. Yoshida T, Sasaki M, Yoshida M, et al. Nationwide survey of Alexander disease in Japan and proposed new guidelines for diagnosis. J Neurol 2011;258: 1998-2008.

2. Tsuji S, Onodera O, Goto J, Nishizawa M; Diseases OBotSGoA. Sporadic ataxias in Japan-a population-based epidemiological study. Cerebellum 2008; 7:189-197.

3. Namekawa M, Takiyama Y, Aoki Y, et al. Identification of GFAP gene mutation in hereditary adult-onset Alexander's disease. Ann Neurol 2002;52:779-785.

4. Namekawa M, Takiyama Y, Honda J, Shimazaki H, Sakoe K, Nakano I. Adult-onset Alexander disease with typical "tadpole" brainstem atrophy and unusual bilateral basal ganglia involvement: a case report and review of the literature. BMC Neurol 2010;10: 21.

5. Cvetanovic M, Ingram M, Orr H, Opal P. Early activation of microglia and astrocytes in mouse models of spinocerebellar ataxia type 1 . Neuroscience 2015;289: 289-299.

6. Meunier C, Merienne N, Jollé C, Déglon N, Pellerin L. Astrocytes are key but indirect contributors to the development of the symptomatology and pathophysiology of Huntington's disease. Glia 2016;64:1841-1856.

7. Yang Y, Muzny DM, Reid JG, et al. Clinical whole-exome sequencing for the diagnosis of mendelian disorders. N Engl J Med 2013;369:1502-1511. 


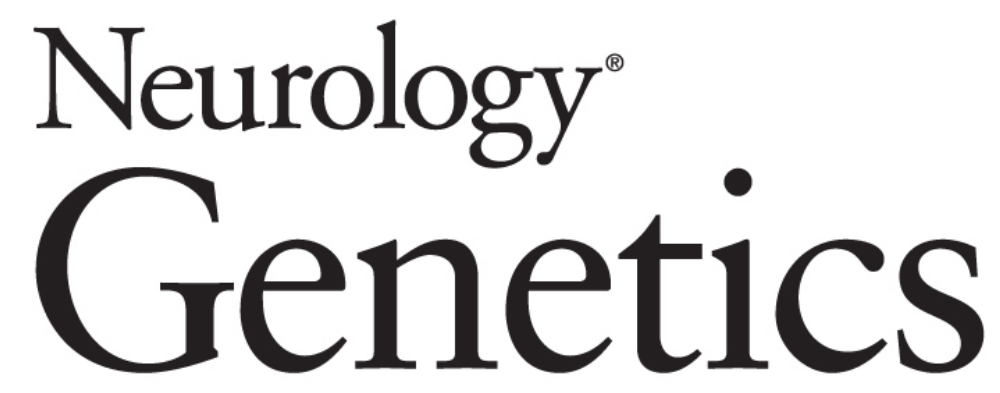

Blended phenotype of adult-onset Alexander disease and spinocerebellar ataxia type 6 Takashi Odo, Tomoko Okamoto, Noriko Sato, et al. Neurol Genet 2020;6;

DOI 10.1212/NXG.0000000000000522

This information is current as of October 2, 2020

Neurol Genet is an official journal of the American Academy of Neurology. Published since April 2015, it is an open-access, online-only, continuous publication journal. Copyright Copyright ( 2020 The Author(s). Published by Wolters Kluwer Health, Inc. on behalf of the American Academy of Neurology.. All rights reserved. Online ISSN: 2376-7839.

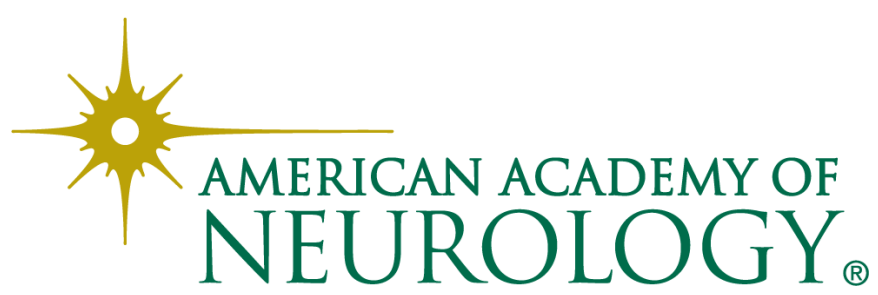




\section{Updated Information \& Services}

References

Subspecialty Collections

Permissions \& Licensing

\section{Reprints}

including high resolution figures, can be found at:

http://ng.neurology.org/content/6/6/e522.full.html

This article cites 7 articles, 0 of which you can access for free at: http://ng.neurology.org/content/6/6/e522.full.html\#\#ref-list-1

This article, along with others on similar topics, appears in the following collection(s):

\section{Cerebellum}

http://ng.neurology.org//cgi/collection/cerebellum

Gait disorders/ataxia

http://ng.neurology.org//cgi/collection/gait_disorders_ataxia

\section{MRI}

http://ng.neurology.org//cgi/collection/mri

Spinocerebellar ataxia

http://ng.neurology.org//cgi/collection/spinocerebellar_ataxia

Trinucleotide repeat diseases

http://ng.neurology.org//cgi/collection/trinucleotide_repeat_diseases

Information about reproducing this article in parts (figures,tables) or in its entirety can be found online at:

http://ng.neurology.org/misc/about.xhtml\#permissions

Information about ordering reprints can be found online:

http://ng.neurology.org/misc/addir.xhtml\#reprintsus

Neurol Genet is an official journal of the American Academy of Neurology. Published since April 2015, it is an open-access, online-only, continuous publication journal. Copyright Copyright $\odot 2020$ The Author(s). Published by Wolters Kluwer Health, Inc. on behalf of the American Academy of Neurology.. All rights reserved. Online ISSN: 2376-7839.

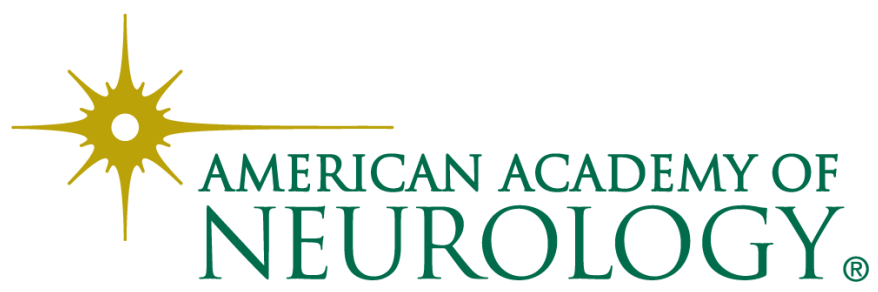

